Tersedia online di http://ejournal-balitbang.kkp.go.id/index.php/jp
e-mail:jurnalpari@gmail.com
Jurnal Pari
Volume 2 Nomor 2 Desember 2016
p-ISSN : 2502-0730
e-ISSN : 2549-0133

\title{
PERPUSTAKAAN KAFE: KONSEP UNIK SEBAGAI USAHA PENINGKATAN MINAT BACA DAN INTERAKSI SOSIAL
}

\section{CAFÉ LIBRARY : UNIQUE CONCEPT AS EFFORT TO INCREASE INTEREST IN READING AND SOCIO - INTERACTION}

\author{
Ketut Masiani \\ Balai Besar Penelitian dan Pengembangan Budidaya Laut \\ Diterima tanggal : 14 Juni 2016 Diterima setelah perbaikan : 23 Agustus 2016 \\ disetujui terbit : 31 Oktober 2016
}

\begin{abstract}
ABSTRAK
Berbagai permasalahan saat ini dihadapi oleh perpustakaan. Perkembangan teknologi informasi dan komunikasi, serta rendahnya minat baca merupakan permasalahan yang harus segera di atasi. Rendahnya minat baca masyarakat saat ini merupakan ancaman serius yang sedang dihadapi oleh bangsa Indonesia. Indeks membaca di Indonesia masih sangat rendah sehingga berpengaruh terhadap tingkat kualitas sumberdaya manusia yang dimiliki. Perpustakaan sebagai lembaga yang bertugas dalam upaya peningkatan minat baca perlu melakukan terobosan baru sehingga minat baca masyarakat dapat meningkat. Perpustakaan kafe merupakan perpustakaan yang menggabungkan desain antara perpustakaan dengan kafe dengan tetap mengedepankan tujuan dan peranan perpustakaan. Tujuan pengembangan perpustakaan kafe ini adalah untuk dapat memberikan kesan baru pada perpustakaan berupa tempat yang nyaman, menyenangkan sehingga dapat menarik minat masyarakat untuk berkunjung, membaca koleksi yang tersedia sehingga mampu meningkatkan minat baca, yang akan berpengaruh dalam peningkatan kecerdasan bangsa dan Negara. Ruangan perpustakaan didesain seperti kafe dengan mengutamakan kenyamanan pengunjung serta penyediaan koleksi yang dapat menarik perhatian masyarakat untuk membacanya. Pengembangan perpustakaan kafe perlu memperhatikan lokasi, desain, koleksi, kerjasama dan jenis layanannya. Pengembangan perpustakaan ini merupakan upaya untuk mengoptimalkan tugas pokok dan fungsi dari perpustakaan, meningkatkan minat baca masyarakat serta sebagai media interaksi sosial masyarakat
\end{abstract}

Kata Kunci : minat baca, perpustakaan kafe, interaksi sosial

\begin{abstract}
A lot of problems being faced by the library nowadays. The growth of information and communication technology, and the low interest in reading must be overcome. Low reading interest in today's society is a serious threat being faced by Indonesia. Reading index in Indonesia is still very low and therefore contributes to the quality level of its human resources. Library as an institution in charge of the effort to increase reading interest need to make new breakthroughs for it. Library cafe is a library that combines the design of a library with a café while still promoting the purpose and role of the library. The purpose of developing a cafe library is to give a new impression of a library as a comfortable and fun place to attract people to visit and read the available collections so as to increase their reading interest, which will take effect in improving national intelligence. Library room is designed like a cafe which emphasizes comfort for visitor as well as provision of a collection that can attract people to read it. The library café development must take into account its location, design, collection, cooperation and kinds of services. The development of this library is an attempt to optimize the duties and functions of the library, to increase public interest as well as to serve as a social media of interaction
\end{abstract}

Keywords: interest in reading, library café, social interaction

Korespondensi Penulis :

Br. Gondol.Desa Penyabangan,Kec.Gerokgak,Kab. Buleleng, PO.BOX 140 Singaraja-Bali 81155

Email : ktmasiani@gmail.com 


\section{PENDAHULUAN}

Perkembangan teknologi informasi dan komunikasi harus dihadapi oleh perpustakaan dalam upaya untuk mampu bersaing dengan sumber informasi lainnya. Perpustakaan perlu mencari terobosan atau inovasi baru yang mampu menarik minat pengguna untuk tetap memanfaaatkan perpustakaan sebagai sumber informasi. Peranan perpustakaan tidak jauh berbeda dengan penyedia informasi lainnya yang berkembang saat ini. Perpustakaan merupakan lembaga yang berperan dalam mendukung upaya untuk mencerdaskan kehidupan bangsa, sebagai lembaga belajar sepanjang hayat serta sebagai lembaga sumber informasi. Selain itu juga sebagai pendukung dalam kegiatan penelitian dan membantu meningkatkan pendidikan, pengetahuan serta wawasan baru. Pengembangan perpustakaan perlu dilakukan untuk memenuhi berbagai tuntutan dan kebutuhan masyarakat pengguna serta perkembangan teknologi yang sedang terjadi. Perpustakaan harus mampu bersaing dengan sumber informasi lain baik dalam pengelolaan informasinya maupun dalam pelayanan terhadap pengguna atau pencari informasi.

Hal terpenting yang perlu diperhatikan adalah memahami perkembangan gaya hidup pengguna dalam kesehariannya dan dalam pencarian informasi. Hal ini sangat penting karena akan mempermudah dalam upaya penyesuaian pengguna dengan pelayanan yang diberikan. Pemahaman ini juga akan membantu mengenai model pengembangan perpustakaan yang akan dilakukan. Pengembangan perpustakaan merupakan aktivitas yang tidak dapat ditunda lagi dan mutlak dilakukan karena perpustakaan merupakan salah satu bentuk organisasi yang harus terus dikembangkan. Di dalam UndangUndang Nomor 43 Tahun 2007 tentang Perpustakaan disebutkan bahwa dalam rangka meningkatkan kecerdasan bangsa perlu ditumbuhkan budaya gemar membaca melalui pengembangan dan pendayagunaan perpustakaan sebagai sumber informasi yang berupa karya tulis, karya cetak dan atau karya rekam. Dari poin ini sudah dapat disimpulkan bahwa dalam upaya peningkatan kecerdasan bangsa perlu dilakukan upaya peningkatan minat baca dengan melakukan pengembangan perpustakaan serta pendayagunaan koleksi perpustakaan secara optimal. Pengembangan perlu terus dilakukan karena adanya persaingan teknologi sumber informasi, tuntutan dan kebutuhan informasi. Pengembangan perpustakaan tentu akan sesuai dengan salah satu hukum dari perpustakaan bahwa perpustakaan merupakan organisasi yang terus berkembang (The Library is a Growing Organism) (Ranganathan, 1931).

Pada saat ini banyak perpustakaan yang kurang siap menghadapi perkembangan teknologi informasi serta tututan kebutuhan pengguna literature. Selain itu pengguna masih memiliki tingkat minat baca yang rendah serta minim pemahamannya tentang peran dan fungsi perpustakaan. Hal ini mengakibatkan masih sedikit masyarakat yang berkunjung dan mencari informasi di perpustakaan. Dengan latar belakang tersebut maka sebagai pustakawan atau pengelola perpustakaan perlu melakukan inovasi dan usaha -usaha untuk mengoptimalkan kembali peran dan fungsi perpustakaan. Salah satu yang dapat dilakukan yaitu penataan ruang perpustakaan dengan konsep unik yang mampu menarik pengguna untuk berkunjung ke perpustakaan. Perancangan perpustakaan dengan konsep kafe ini bertujuan untuk dapat memberikan kesan baru pada perpustakaan berupa tempat yang nyaman, menyenangkan sehingga dapat menarik minat masyarakat untuk berkunjung, membaca koleksi yang tersedia sehingga mampu meningkatkan minat baca, yang akan berpengaruh dalam peningkatan kecerdasan bangsa dan negara. Selain itu dengan desain ini akan dapat menunjukkan bahwa perpustakaan tidak hanya untuk mencari buku dan informasi akan tetapi juga tempat yang nyaman dalam berinteraksi, berdiskusi, serta memberikan suasana santai yang menarik bagi masyarakat pengguna.

\section{TINJAUAN PUSTAKA 1.1.Perpustakaan}

Pengertian perpustakaan tercantum dalam Undang-Undang No.43 tahun 2007 tentang 
Perpustakaan pada Bab I Pasal 1 yang menyebutkan bahwa perpustakaan adalah institusi pengelola koleksi karya tulis, karya cetak, dan/atau karya rekam secara profesional dengan sistem yang baku guna memenuhi kebutuhan pendidikan, penelitian, pelestarian, informasi, dan rekreasi para pemustaka. Pengertian lain tentang perpustakaan juga dapat dilihat dari pendapat beberapa pakar perpustakaan diantaranya:

> Perpustakaan adalah suatu ruangan, bagian dari gedung/bangunan, atau gedung itu sendiri, yang berisi buku-buku koleksi, yang disusun dan diatur sedemikian rupa sehingga mudah dicari dan dipergunakan apabila sewaktu-waktu diperlukan untuk pembaca (Sutarno, 2003).

$>$ Perpustakaan merupakan kumpulan bahan tercetak dan non tercetak dan atau sumber informasi dalam komputer yang tersusun secara sistematis untuk kepentingan pemakai, International of Library Associations and Institutions dalam Basuki (2003).

Dari beberapa pendapat tersebut dapat disebutkan bahwa perpustakaan adalah suatu ruangan yang berisi buku baik tercetak maupun non tercetak yang digunakan sebagai sumber informasi bagi pemakainya. Seiring dengan perkembangan yang ada saat ini perpustakaan perlu melakukan perubahan-perubahan untuk dapat kembali menjadi sumber informasi serta mampu mencapai tujuan dari lembaga perpustakaan yaitu menyediakan fasilitas dan sumber informasi serta menjadi pusat pembelajaran (Sutarno, 2006). Sedangkan (Lasa, 2007) menyebutkan tujuan perpustakaan adalah:
a. Menumbuh kembangkan minat baca dan tulis.
b. Mengenalkan teknologi informasi.
c. Membiasakan akses informasi secara mandiri.
d. Memupuk bakat dan minat.

\subsection{Pengembangan Perpustakanan}

Mempertahankan peranan perpustakaan tentu harus melakukan perubahan-perubahan yang mampu memenuhi kebutuhan pengguna dan menghadapi persaingan teknologi informasi. Perpustakaan juga perlu melakukan inovasi-inovasi baik dalam layanan, kegiatannya maupun dalam penyediaan sarana dan prasananya. Lebih jelas tentang pengembangan perpustakaan dicantumkan dalam Undang-undang Nomor 43 Tahun 2007 tentang Perpustakaan Bab VI Pasal 19 bahwa pengembangan perpustakaan merupakan upaya peningkatan sumber daya, pelayanan, dan pengelolaan perpustakaan, baik dalam hal kuantitas maupun kualitas. Senada dengan Haryanti (2010) inovasi pengembangan perpustakaan dapat meliputi 4 bagian yaitu:

1. Inovasi Layanan Inovasi layanan perpustakaan merupakan inovasi yang dilakukan dalam upaya menemukan metode atau cara baru untuk peningkatan layanan perpustakaan kepada pengguna. Beberapa inovasi dibidang layanan dapat dilakukan melalui:

a. Fasilitas yaitu dengan menyediakan fasilitas yang memadai, terkini sesuai dengan media teknologi yang berkembang misalnya komputer terbaru dengan jaringan internet yang memadai.

b. Petugas yang berkompetensi yaitu petugas yang memiliki kemampuan dalam memberikan pelayanan kepada pengguna, memiliki wawasan yang luas, mampu berinteraksi yang baik dan memiliki semangat untuk terus berkembang.

c. Kenyamanan dapat meliputi penataan ruang, pengaturan kondisi dan situasi yang nyaman, menyenangkan serta desain yang menarik.

d. Koleksi yang beragam yaitu menyediakan koleksi yang terbaru, lengkap dan beragam sesuai dengan kebutuhan pengguna.

2. Inovasi Kegiatan

Inovasi kegiatan sangat penting dilakukan dalam upaya untuk menjaga keberlanjutan peranan perpustakaan bagi pengguna. Perpustakaan perlu membuat kegiatan-kegiatan yang mampu menarik pengguna untuk lebih memanfaatkan perpustakaan serta meningkatkan 
partisipasi pengguna dalam kegiatan perpustakaan. Dengan partisipasi pengguna ini perpustakaan akan lebih memahami kebutuhan pengguna serta akan memberikan pemahaman juga kepada pengguna bahwa perpustakaan itu bukan hanya sebagai gudang buku akan tetapi juga sebagai media untuk menambah wawasan masyarakat, media interaksi dan rekreasi yang kedepannya dapat menarik pengguna untuk lebih memanfaatkan perpustakaan.

3. Inovasi Pemberdayaan Masyarakat :

Pemberdayaan masyarakat pengguna merupakan bagian terpenting dalam mengenalkan lebih dalam mengenai perpustakaan. Perpustakaan dapat melibatkan pengguna dalam kegiatan yang diselenggarakan perpustakaan. Pada era teknologi canggih ini perpustakaan dapat melibatkan pengguna dalam pengelolaan perpustakaan. Salah satu contoh yang saat ini dikembangkan adalah perpustakaan yang berbasis web 2.0. Perpustakaan 2.0 adalah perpustakaan yang benar-benar beorientasi kepada pemakai, yang mendorong perubahan secara terus menerus, yang mengkreasikan layanan baik fisik maupun maya sesuai dengan keinginan pemakai, yang didukung dengan evaluasi layanan secara konsisten (Suwanto, 2013). Dengan pengembangan perpustakaan ini maka pengguna akan terlibat secara langsung dalam perpustakaan. Selain itu perpustakaan dapat berperan sebagai penggerak dan sumber informasi bagi masyarakat sehingga masyarakat dapat diberdayakan sesuai dengan potensi yang dimilki oleh masyarakat dan wilayahnya sehingga dapat meningkatkan derajat dan kualitas serta meningkatkan perekonomian masyarakat.

4. Inovasi Kemitraan/Kerjasama :

Menghadapi perkembangan teknologi informasi saat ini, untuk mempertahankan keberadaan perpustakaan perlu melakukan kerjasama dengan lembaga perpustakaan lain. Selain itu perpustakaan juga dapat melakukan kerjasama dengan pusat informasi lain sehingga berbagai kebutuhan pengguna akan informasi dapat dipenuhi.

\subsection{Perpustakaan Kafe}

Kamus Besar Bahasa Indonesia (2012) menyebutkan bahwa kafe adalah kedai kopi/tempat minum yang pengunjungnya dapat memesan minuman, seperti kopi, teh, dan kue-kue. Menyebut kata perpustakan secara umum masyarakat berpendapat bahwa perpustakaan merupakan suatu gedung/ruangan yang penuh dengan deretan buku-buku, dengan situasi yang sunyi senyap dan merupakan tempat yang kurang menarik untuk dikunjungi. Menyikapi pendapat ini maka sudah waktunya perpustakaan melakukan perubahan yang mampu mengubahnya menjadi tempat yang menarik untuk dikunjungi. Salah satu yang dapat dilakukan yaitu melakukan desain ruangan sehingga menimbulkan kesan yang nyaman, menarik dan santai. Seperti hasil penelitian (Sainttyauw, 2013) menyimpulkan bahwa desain interior perpustakaan merupakan unsur penting dalam pengembangan perpustakaan karena ada pengaruh secara simultan yang ditimbulkan oleh desain interior yang meliputi ruang, variasi, hirarki, area personal, pencahayaan, tata suara, suhu udara, perawatan, kualitas udara, gaya dan fashion terhadap kenyamanan pengguna di perpustakaan. Perubahan desain perpustakaan yang menggabungkan desain kafe memungkinkan mengubah pandangan masyarakat tentang perpustakaan. Perpustakaan dengan konsep Kafe dapat dijadikan alternatif untuk meningkatkan minat baca masyarakat $\left(\right.$ Anonim $\left.^{\mathrm{b}}, 2013\right)$. Perpustakaan kafe merupakan salah satu inovasi dalam pengembangan perpustakaan sebagai upaya peningkatan pengunjung, meningkatkan minat baca masyarakat serta pengoptimalan pemanfaatan perpustakaan sebagai sumber informasi dan pendidikan sepanjang hayat. Jadi dapat disebutkan bahwa perpustakaan kafe adalah perpustakaan yang menggunakan konsep kafe yaitu perpustakaan yang didesain dengan suasana kafe didalammnya, menyediakan makanan dan minuman ringan di perpustakaan, suasana yang santai dan 
nyaman dengan tetap mengutamakan fungsi perpustakaan.

\subsection{Media interaksi sosial}

Fenomena yang saat ini terjadi akibat perkembangan teknologi informasi dan komunikasi adalah semakin jarangnya seseorang mau bertegur sapa dengan orang sekelilingnya, mereka akan sibuk sendiri dengan gadget yang dipegangnya. Hal ini tentunya akan semakin mengurangi rasa kebersamaan dan kepedulian seseorang dengan lingkungan sekitarnya. Selain itu pada saat ini mayoritas masyarakat memiliki rutinitas yang padat yang menuntut aktivitas penuh sepanjang hari. Hal ini tentunya akan sangat mengurangi waktu kebersamaan mereka bersosialisasi dengan keluarga maupun dengan teman-temannya. Kebanyakan remaja saat ini mengisi waktu luangnya dengan berkumpul bersama dan menikmati kebersamaan dengan nongkrong/berkumpul-kumpul di kafe. Tempat sejenis kafe merupakan "tempat ketiga" yang menciptakan persahabatan dan sosialisasi selain di rumah dan tempat kerja (Oldenburg dalam Setiati, 1989). Dengan memperhatikan gaya hidup saat ini maka perpustakaan dapat memanfaatkan kondisi ini dengan pengembangan perpustakaan kafe.

\section{METODE}

Metode yang digunakan dalam penulisan makalah ini yaitu metode deskriptif dan melalui studi pustaka. Dalam studi pustaka diperoleh dari buku-buku mengenai perpustakaan, artikel jurnal, makalah/artikel online serta melalui artikel-artikel yang termuat dalam media cetak yang berkaitan dengan perpustakaan kafe. Penulisan ini diawali dengan penentuan judul sesuai dengan topik yang telah ditetapkan, pengumpulan informasi untuk sumber literatur dan pembuatan konsep abstrak.

\section{HASIL DAN PEMBAHASAN}

Perpustakaan pada saat ini dituntut untuk mampu mengikuti berbagai perkembangan secara cepat dan tepat. Kesan kaku dan model perpustakaan yang monoton dan kurang inovatif, kurang menarik pengguna untuk mengunjunginya. Pengembangan perpustakaan saat ini dilakukan dalam upaya menghadapi berbagai permasalahan terkait rendahnya minat baca di Indonesia. Trend perkembangan gaya hidup masyarakat terutama kawula muda sebagai generasi penerus, mengikuti perkembangan teknologi informasi serta berbagai tuntutan kebutuhan masyarakat pengguna. Undang-Undang No.43 tahun 2007 tentang Perpustakaan, Pasal 4 menyebutkan bahwa perpustakaan bertujuan memberikan layanan kepada pemustaka, meningkatkan kegemaran membaca, serta memperluas wawasan dan pengetahuan untuk mencerdaskan kehidupan bangsa. Sedangkan International Federation of Library Associations and Institutions (IFLA), (2015) menyebutkan beberapa peran perpustakaan diantaranya:

- Libraries provide opportunity for all (Perpustakaan memberikan kesempatan bagi semua)

Dengan menyediakan koleksi yang lengkap, perpustakaan memberikan kemudahan bagi masyarakat yang memerlukan buku/koleksi tertentu namun tidak memiliki kemampuan untuk memilikinya. Baik karena alasan ekonomi maupun ketidaktahuan mengenai cara untuk mendapatkannya. Perpustakaan memberikan kesempatan belajar, menambah ilmu pengetahuan, wawasan, hiburan, maupun menyimpan koleksinya kepada semua lapisan masyarakat. Perpustakaan melayani semua orang, tanpa memandang ras, asal nasional atau etnis, jenis kelamin atau preferensi seksual, usia, cacat, agama, keadaan ekonomi atau keyakinan politik.

- Libraries are found in all locations (Perpustakaan ditemukan di semua lokasi) Sebagai lembaga yang berperan dalam meningkatkan kecerdasan bangsa, sumber informasi dan berfungsi sebagai tempat pembelajaran sepanjang hayat maka pembangunan perpustakaan dibangun di seluruh wilayah baik di kota maupun di 
pedesaan. Hal ini akan memungkinkan perpustakaan dapat ditemukan disemua lokasi.

- Libraries underpin a society where people from any background can learn, create and innovate (Perpustakaan mendukung masyarakat di mana orang-orang dari latar belakang apapun bisa belajar, berkreasi dan berinovasi)

Perpustakaan bukanlah lembaga eksklusif yang hanya diperuntukkan bagi golongan tertentu saja. Semua golongan masyarakat memiliki kesempatan untuk memiliki hak akses ke perpustakaan sehingga mendukung usaha pembelajaran bagi seluruh lapisan masyarakat. Perpustakaan dapat dimanfaatkan oleh semua orang tanpa memandang umur, ras, golongan, kaya atau miskin dan perbedaan lainnya.

- Libraries offer access to the world's knowledge (Perpustakaan menawarkan akses ke dunia pengetahuan)

Dengan menyediakan berbagai koleksi perpustakaan memberikan kemudahan untuk memiliki informasi, wawasan dan pengetahuan. Banyak hal yang bisa diperoleh dari membaca buku karena buku adalah jendela dunia.

- Librarians provide expert guidance (Pustakawan memberikan bimbingan ahli) Tidak semua orang memiliki kemampuan dalam hal melakukan penelusuran informasi. Di perpustakaan masyarakat/pengguna akan mendapatkan bantuan dari pustakawan yang memiliki keahlian dalam penelusuran dan literasi informasi. Selain itu juga akan mendapatkan layanan referensi yaitu layanan perpustakaan yang fokus pada koleksi dan pertanyaan rujukan yang bertujuan untuk membantu pemakai yang mengalami kesulitan dalam mencari dan mendapatkan informasi yang relevan sesuai dengan keperluan, baik secara perorangan seperti menjawab pertanyaan, maupun kepada kelompok, seperti memberikan bimbingan (Bibliogrphic Instruction), (Bunge and Bopp dalam Musa, 2012).
- Libraries are part of a multistakeholder society (Perpustakaan adalah bagian dari masyarakat multistakeholder).

Perpustakaan menghimpun dan menyediakan koleksi dari berbagai disiplin ilmu. Sebagai lembaga sumber informasi, perpustakaan merupakan lembaga yang dibutuhkan oleh seluruh masyarakat yang terdiri dari berbagai profesi. Dengan demikian perpustakaan memiliki arti penting bagi semua lapisan masyarakat dan diberbagai sektor pembangunan.

- Libraries must be recognised in development policy frameworks (Perpustakaan harus diakui dalam kerangka kebijakan pembangunan)

Dengan posisi strategis dalam peningkatan sumber daya manusia, maka selayaknya pengembangan perpustakaaan selalu disertakan dalam kebijakan pembangunan nasional. Sebagai lembaga yang mengemban tugas untuk mencerdaskan kehidupan bangsa maka perpustakaan sudah semestinya diperhitungkan dan dilibatkan dalam pengambilan kebijakan pemerintah. Selain itu juga perlu diberikan perhatian khusus terutama dalam pembangunan dan pengembangannya karena perpustakaan merupakan lembaga yang selalu dan terus berkembang seiring dengan perkembangan teknologi informasi dan komunikasi.

Dari uraian tersebut dapat disimpulkan bahwa perpustakaan memegang peranan yang penting dalam mencerdaskan kehidupan bangsa sehingga perpustakaan merupakan lembaga penting yang perlu mendapat perhatian oleh semua pihak dan perlu dipertahankan keberadaanya. Salah satu permasalahan yang dihadapi dan harus segera diatasi oleh perpustakaan adalah rendahnya minat baca masyarakat. Pengelola perpustakaan sudah semestinya memahami penyebab utama dari rendahnya minat baca yang terjadi saat ini diantaranya belum tertanamnya budaya membaca (Sularsih, 2015). 
Adanya persaingan bebas seperti Masyarakat Ekonomi ASEAN (MEA) menuntut kualitas sumberdaya manusia yang siap bersaing. Kemampuan bersaing ini tentunya ditentukan oleh keahlian dan pengetahun yang dimiliki oleh seseorang. Sebagai salah satu metode memperoleh pengetahuan dan informasi adalah dengan membaca. Rendahnya minat baca yang terjadi dikalangan kawula muda tentunya akan sangat berpengaruh terhadap kualitas sumberdaya manusia dan daya saing yang dimilikinya. Ketidakmampuan dalam bersaing akan menyebabkan semakin tersingkirnya sumberdaya manusia dalam negeri oleh sumberdaya manusia yang berasal dari luar negeri dan akan semakin tertinggal dari negara lain. Bisa dibayangkan apabila sebagaian besar komponen tenaga kerja, inovasi, ilmu pengetahuan dan lain sebagainya dikuasai oleh pihak asing maka disinilah mulainya penguasaan negara asing di Indonesia.

Perkembangan teknologi informasi yang terjadi saat ini tidaklah menjadi alasan untuk tidak membaca buku karena buku merupakan media sumber informasi yang mampu meningkatkan kualitas pembacanya dan merupakan amunisi dan meriam dalam menghadapi era regionalisasi dan globalisasi ini (Hardono, 2016). Hal senada juga diungkapkan Eliot dalam Khoiri (2015) bahwa sulit membangun peradaban tanpa budaya tulis dan baca. Hal ini menegaskan bahwa membaca merupakan kegiatan yang sangat penting yang perlu ditanamkan sejak usia dini sehingga membaca sudah menjadi suatu kebiasaan.

Membaca merupakan kegiatan penting yang harus dilakukan oleh seluruh lapisan masyarakat. Banyak manfaat yang diperoleh dari membaca diantaranya dapat menambah wawasan baru, mendapatkan hiburan, menambah kosakata, meningkatkan rasa percaya diri dan sebagainya (Acosmin, 2013) menyebutkan bahwa ada 10 alasan penting membaca buku yaitu:

1. To Develop Your Verbal Abilities (Menambah kosakata)

2. Improves Your Focus and Concentration (Meningkatkan kosentrasi)
3. Readers Enjoy The Arts and Improve The World (Pembaca menikmati seni dan lebih aktif dalam lingkungan sekitarnya)

4. It Improves Your Imagination (Meningkatkan daya imajinasi)

5. Reading Makes You Smarter (Membaca akan mencerdaskan)

6. It Makes You Interesting And Attractive (Menjadi orang yang menarik dan menyenangkan )

7. It Reduces Stress (Mengurangi stres)

8. It Improves Your Memory (Meningkatkatkan daya ingat)

9. To Discover and Create Yourself (Mengetahui/memahami diri mereka sendiri)

10. For Entertainment (Membaca sebagai hiburan)

Demikian juga Abreu ( 2015) menyampaikan beberapa alasan mengenai pentingnya membaca yaitu:

1. To Improve memory (Meningkatkan daya ingat)

2. To Development vocabulary (Menambah kosakata)

3. To reduce stress (Mengurangi stres)

4. To improve concentration (Meningkatkan kosentrasi)

5. To Improve our imagination (Meningkatkan daya imajinasi)

6. To have Fun (Memperoleh hiburan)

Dari pendapat-pendapat tersebut dapat diketahui bahwa membaca merupakan kegiatan penting yang seharusnya menjadi kebiasaan dan menjadi suatu keinginan/minat bagi setiap generasi. Minat baca merupakan salah satu komponen penting yang harus dimiliki oleh setiap generasi dalam upaya untuk menambah pengetahuan dan informasi. Membaca merupakan salah satu cara untuk memperoleh suatu informasi. Ada beberapa tujuan dari membaca yaitu hiburan, mencari informasi yang dibutuhkan maupun sebagai media pembelajaran. Secara umum tingkat minat baca akan berbanding lurus dengan tingkat intelektualitas seseorang. Banyaknya membaca tidak hanya akan menambah wawasan dan informasi namun juga akan menambah berbagai keahlian salah satunya adalah menulis. 
Di negara-negara maju membaca sudah merupakan suatu rutinitas dan sudah menjadi kebiasaan. Masyarakat akan mengisi waktu luangnya dengan membaca. Berbeda halnya dengan masyarakat di Indonesia bahwa membaca merupakan kegiatan yang hanya dilakukan oleh kalangan tertentu dan dilakukan sebagai tugas bukan sebagai rutinitas. Masyarakat Indonesia sangat jarang ditemui membaca dalam kesehariannya. Banyak usia anak-anak dan remaja yang semestinya menjadikan membaca sebagai rutinitas tidak melakukan kegiatan membaca, apalagi bagi mereka yang usianya sudah senja. Kondisi ini menyebabkan bangsa Indonesia semakin terbelakang dan ditinggalkan oleh negaranegara yang dominan penduduknya rajin membaca. Hal ini terbukti dari tingkat kemajuan negara, inovasi yang dihasilkan serta kompetensi tenaga kerja yang siap bersaing. Global Competitiveness Report 2015-2016 yang dirilis WEF (World Economic Forum) dalam Supriadi (2015) menyampaikan bahwa daya saing Indonesia kalah dari tiga negara tetangga, yakni Singapura yang berada di peringkat 2, Malaysia di peringkat 18 dan Thailand di urutan 32. Laporan ini menunjukkan bahwa kualitas sumberdaya manusia yang dimiliki Indonesia masih rendah sehingga kalah bersaing dengan negara tetangga.

Perkembangan teknologi informasi dan komunikasi serta cepatnya perputaran informasi yang terjadi saat ini, apabila tidak diimbangi dengan minat baca yang tinggi akan ketinggalan informasi dan inovasi yang terjadi sehingga menyebabkan semakin tertinggal terutama dalam kompetensi tenaga kerja. Di kutip dari harian kompas, 2016 bahwa dari Kajian Perpustakaan Nasional 2015 menunjukkan minat baca masyarakat masih 25,1 atau rendah. Data dari UNESCO pada tahun 2011 menyatakan bahwa indeks baca di Indonesia hanya 0,001 persen dan ini artinya, dari seribu penduduk hanya terdapat satu orang yang gemar membaca (Taylor, 2015). Kondisi ini tentunya merupakan gambaran bahwa kondisi tingkat minat baca di Indonesia sudah sangat rendah dan sangat memprihatinkan yang kedepannya akan menimbulkan kualitas sumber daya manusia tidak mampu bersaing. Selain itu, Data Statistik
Sosial Budaya tahun 2012 dalam Erawan (2012) menunjukkan bahwa masyarakat Indonesia belum menjadikan kegiatan membaca sebagai sumber utama mendapatkan informasi dimana sebanyak 91,68 persen penduduk yang berusia 10 tahun ke atas lebih menyukai menonton televisi, dan hanya sekitar 17,66 persen yang menyukai membaca surat kabar, buku atau majalah. Sementara dari Organization for Economic Cooperation and Development (OECD) pada tahun 2009 menempatkan minat baca Indonesia pada posisi terendah dari 52 Negara Asia Timur (Anonim, 2014). IMD World Talent Report 2015 dalam Ngasuko (2015) menyatakan bahwa sebagai lembaga yang mensurvei tenaga berbakat dan terampil di dunia tahun 2015 peringkat Indonesia turun 16 peringkat, dari peringkat ke-25 pada tahun 2014 menjadi peringkat ke-41 pada tahun 2015. Posisi Indonesia berada jauh di bawah posisi negara tetangga seperti Singapura, Malaysia, bahkan Thailand. Masih menurut hasil survey tersebut faktor kesiapan sumber daya manusia merupakan yang paling dominan menyumbang angka penurunan peringkat tenaga terampil Indonesia di tahun 2015. Hal ini menunjukkan bahwa Indonesia masih belum mampu sepenuhnya bersaing dalam hal kesiapan tenaga kerja. Salah satu upaya yang paling penting dilakukan untuk mengatasi hal ini adalah melalui pendidikan dan peningkatan minat baca karena membaca adalah kunci setiap pintu ilmu dan pengetahuan (Ansyori, 2013). Membaca juga dapat menambah serta memperluas wawasan dan pengetahuan yang akan membuat seseorang menjadi lebih cerdas dan mampu menangkap pengetahuan baru (Manis, 2010). Roger Farr dalam Radesi (2013) mengemukakan bahwa "Reading is the heart of Education." Artinya membaca adalah jantungnya pendidikan. Dari pernyataaan ini diartikan bahwa dengan membaca kita akan belajar dan bernalar untuk mendapatkan informasi - informasi penting yang dapat menjadi sarana untuk memperoleh kehidupan yang lebih baik.

\section{Konsep Unik Perpustakaan Kafe}

Perpustakaan kafe merupakan konsep unik yang saat ini patut dipertimbangkan 
kehadirannya dan merupakan salah satu terobosan baru dalam menciptakan suasana baru pada perpustakaan sehingga memberikan kesan yang unik dan dapat menarik minat masyarakat. Menurut penelitian The Nielsen Regional Retail Highlights dalam Kartika, 2012 bahwa banyak kawula muda mengunjungi tempat sejenis resto karena konsep tempat dianggap sesuai dengan gaya hidup orang Indonesia. Dengan hasil penelitian ini, perpustakaan dapat memanfaatkan kegemaran kawula muda ini dengan pengembangan perpustakaan berkonsep kafe sehingga memungkinkan menjaring mereka untuk berkunjung ke perpustakaan. Perpustakaan kafe ini dapat dibentuk pada semua jenis perpustakaan. Dalam penataan ruangannya sebuah perpustakaan secara menyeluruh dapat mengadopsi penataan ruangan kafe yang secara umum mengedepankan kenyamanan pengunjung sedangkan untuk layanan perpustakaan, yang menyediakan makanan dan minuman dapat dikhususkan dalam sebuah tempat/ruangan. Konsep perpustakaan kafe ini memadukan antara desain,dan layanan kafe dengan tetap mengedepankan peranan dan tujuan sebuah perpustakaan. Sebuah perpustakaan kafe menyediakan berbagai koleksi dan ruangannya ditata senyaman mungkin. Dalam perpustakaan ini juga disediakan berbagai menu pilihan makanan yang dapat dipesan oleh pengunjung sehingga pengunjung dapat membaca, berdiskusi dengan rasa nyaman dan santai sambil menikmati makanan. Secara umum pengunjung kafe melakukan aktivitas hanya untuk bersosialisasi akan tetapi pada perpustakaan kafe pengunjung dapat berdiskusi, membaca buku, belajar serta bersosialisasi sambil menikmati sajian yang dipesan. Hal ini tentunya akan menjadi daya tarik tersendiri bagi perpustakaan kafe sehingga mampu menjadi media pendidikan, sumber informasi, penyimpanan koleksi serta media rekreasi/hiburan. Selain itu ada beberapa keuntungan besar yang diperoleh dari didirikannya perpustakaan dengan konsep kafe yaitu:

a. menjadikan masyarakat gemar berkunjung ke perpustakaan yang dapat menumbuhkan/meningkatkan minat baca

$\begin{array}{lll}\text { masyarakat } & \text { sehingga } & \text { mampu } \\ \text { mencerdaskan } & \text { kehidupan } & \text { bangsa } \\ \left(\text { Anonim }^{b}, 2013\right) . & & \end{array}$

b. mampu menyediakan tempat yang nyaman dan menyenangkan sehingga dapat mengubah pandangan masyarakat mengenai perpustakaan sebagai tempat yang membosankan menjadi tempat yang menyenangkan.

c. mengembalikan fungsi perpustakaan sebagai sumber informasi.

Pengembangan perpustakaan kafe ini juga memiliki beberapa kelemahan diantaranya:

a. memungkinkan buku/koleksi perpustakaan lebih cepat rusak karena terkena makanan/minuman,

b. membutuhkan tenaga selain pustakawan yaitu tenaga yang melayani pemesanan makanan dan minuman.

c. Membutuhkan anggaran/modal yang besar untuk dapat menyediakan fasilitas, desain dan interior perpustakaan.

Secara umum alur aktivitas dan kegiatan pengunjung dalam perpustakaan kafe tidak berbeda jauh dengan aktivitas pengunjung di perpustakaan biasa. Pada perpustakaan kafe kelebihan dan keunikan yang diberikan adalah pengunjung dapat membaca buku koleksi perpustakaan, berdiskusi, menelusuri informasi (browsing) sambil menikmati makanan dan minuman serta kondisi yang nyaman dan santai. Begitu juga dibandingkan aktifitas perpustakaan kafe dengan aktivitas di kafe atau restoran. Alur aktivitas pada perpustakaan kafe dengan kafe atau restoran dapat dilihat pada Gambar 1 berikut:

Pada perpustakaan kafe, pelayan dapat merangkap menjadi pelayan perpustakaan(pustakawan) dan penyaji makanan atau bisa juga berbeda antara penyaji makanan dengan pustakawan. Pengunjung dapat memesan makanan melalui pramusaji serta informasi koleksi melalui pustakawan pada meja resepsionis. 


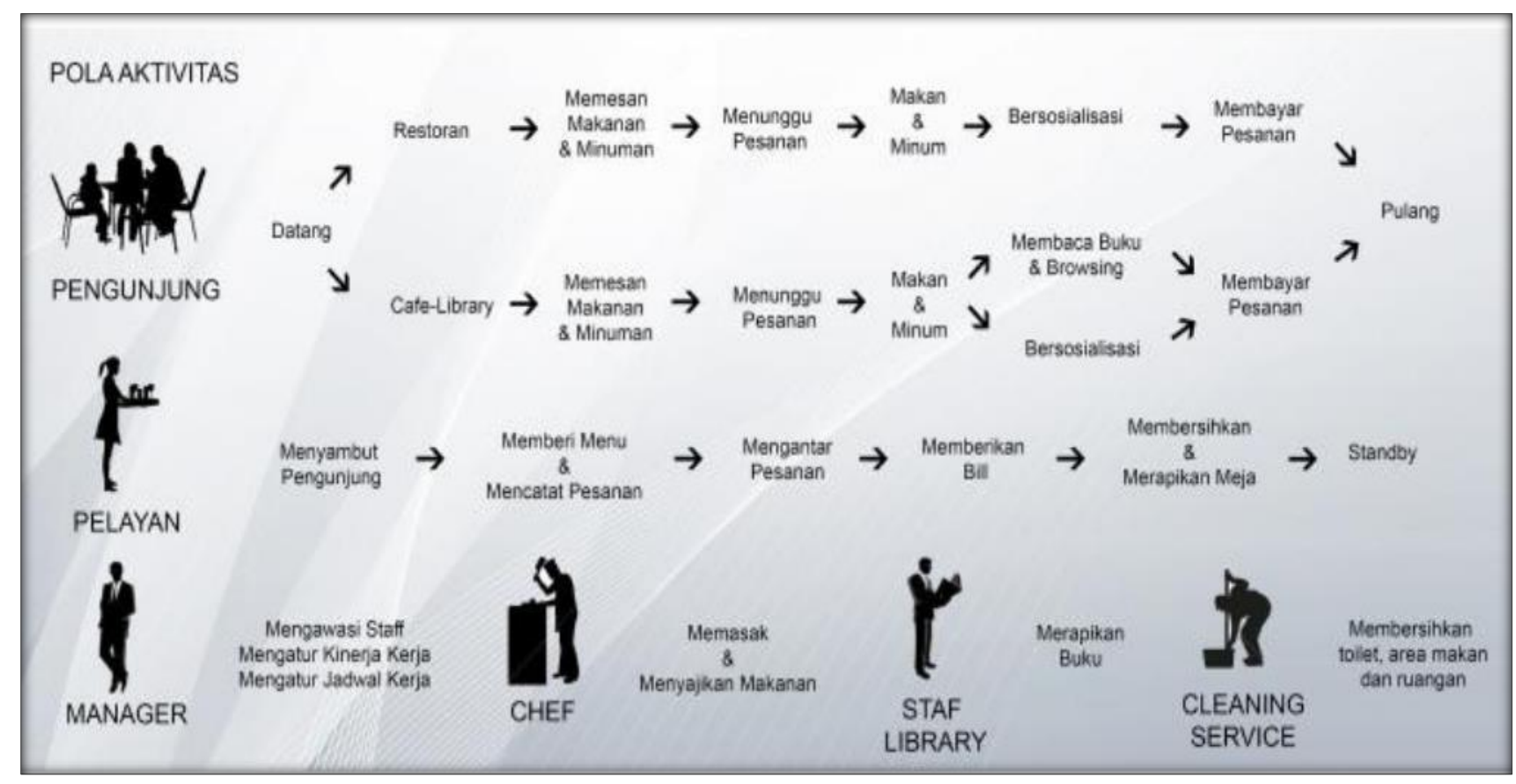

Gambar 1. Pola aktivitas pengunjung perpustakaan dan kafe Sumber : Chandra, RS. 2015. Perancangan Café-Library and Resto di Surabaya

Secara sederhana alur kerja pada pada pramusaji. Setelah mendapat informasi perpustakaan kafe dapat digambarkan pada dan melakukan pemesan makanan serta Gambar 2 sebagai berikut: minuman pengunjung dapat menunggu di meja pengunjung. Sambil menunggu makanan dan

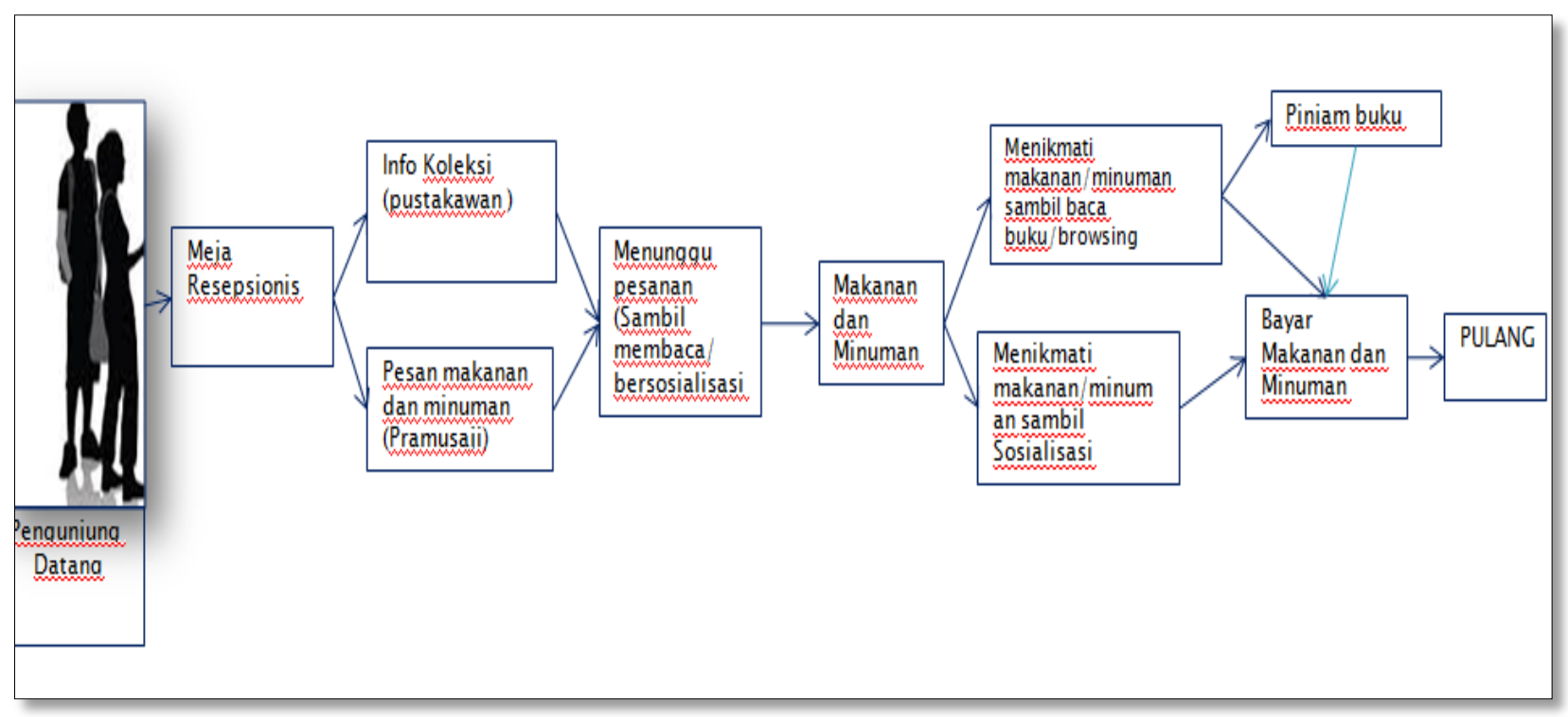

Gambar 2. Alur kerja pada perpustakaan kafe

Gambar diatas dapat dijelaskan bahwa pada perpustakaan kafe, pengunjung yang datang akan menuju ke meja resepsionis/meja pemesanan. Di meja ini, pengunjung dapat mencari informasi mengenai koleksi yang ada ke pustakawan dan dapat memesan makanan minuman yang dipesan pengunjung dapat melakukan penelusuran koleksi pada rak koleksi atau penelusuran informasi melalui media internet yang ada. Setelah makanan dan minuman yang dipesan datang, pengunjung dapat menikmatinya sambil membaca buku 
atau berdiskusi. Apabila pengunjung perpustakaan kafe ingin meminjam buku perpustakaan maka pengunjung dapat menghubungi pustakawan untuk melakukan pencatatan koleksi. Pengunjung dapat meninggalkan perpustakaan kafe, setelah melakukan pencatatan transaksi peminjaman dan telah melakukan pembayaran makanan dan minuman yang dipesan. Begitu juga yang sekedar untuk berdiskusi, berkunjung atau bersosialisasi dapat pulang setelah melakukan pembayaran makanan dan minuman yang dipesan.

\section{Pedoman pengembangan perpustakaan kafe}

Penataan ruangan dan penggunaan sarana dan prasarana dalam perpustakaan kafe dapat meniru kafe atau bar yang berkembang saat ini misalnya kursi dan meja yang memberikan kenyaman bagi pengunjung, tempat pemesanan makanan serta prasarana lain yang digunakan dalam sebuah kafe/bar. Hal terpenting yang perlu juga diperhatikan adalah penataan koleksi yang mudah dijangkau oleh pengunjung. Konsep ini memungkinkan akan dapat menarik minat masyarakat untuk berkunjung ke perpustakaan dan membaca koleksi-koleksi yang ada, berdiskusi dan belajar. Pengembangan perpustakaan kafe perlu dilakukan perencanaan terlebih dahulu sehingga sesuai dengan tujuan dan harapan. Adapun tahap perencanaan dalam pembentukan perpustakaan kafe (Benawi, 2012) yaitu:

a) Pemilihan Ruangan/Lokasi yang Strategis Pemilihan ruangan/lokasi merupakan tahap pertama dan tahap penting dalam pengembangan perpustakaan kafe karena salah satu faktor yang sangat penting dalam menunjang keberhasilan perpustakaan adalah lokasi perpustakaan (Rochadita, 2010). Lokasi perpustakaan harus strategis dan mudah dijangkau pengguna. Menurut Undang-undang Nomor 43 Tahun 2007 tentang Perpustakaan Bab III Pasal 15 Ayat (2) menyatakan bahwa "Lahan perpustakaan harus berlokasi yang mudah diakses, aman, nyaman, dan memiliki status hukum yang jelas". Sebagai lembaga non profit perpustakaan perlu memperhatikan lokasi yang mudah dijangkau atau di akses, memiliki kenyaman dan menarik untuk dikunjungi sehingga mampu menciptakan daya tarik pengguna untuk berkunjung ke perpustakaan. Penentuan lokasi perpustakaan dapat menggunakan pertimbangan penentuan lokasi penyedia jasa yang dicetuskan oleh (Tjiptono, 2004) yang meliputi faktor-faktor:

1. Akses, misalnya lokasi yang dilalui atau mudah dijangkau sarana transportasi umum.

2. Visibilitas/keterlihatan, misalnya lokasi yang dapat dilihat dengan jelas dari tepi jalan.

3. Lalu lintas (traffic), dimana ada dua hal yang perlu dipertimbangkan, yaitu:

a. Banyaknya orang yang lalu-lalang bisa memberikan peluang besar terjadinya impulse buying

b. Kepadatan dan kemacetan lalu lintas bisa pula menjadi hambatan.

4. Tempat parkir yang luas dan aman.

5. Ekspansi, yaitu tersedia tempat yang cukup luas untuk perluasan usaha di kemudian hari.

6. Lingkungan, yaitu daerah sekitar yang mendukung jasa yang ditawarkan.

7. Persaingan, yaitu lokasi pesaing.

8. Peraturan pemerintah.

b) Pemasangan internet atau Wifi

Di era teknologi informasi dan komunikasi internet merupakan kebutuhan utama bagi pengunjung dan merupakan daya tarik perpustakaan untuk menarik minat pengguna berkunjung ke perpustakaan. Pemasangan internet dalam perpustakaan dapat dimanfaatkan untuk penelusuran informasi secara online seperti akses jurnal online, layanan akses katalog secara online (Online Public Catalog Access, OPAC), media pencarian (search engine),dan sebagai media sosial.

c) Koleksi dan Layanan

Koleksi yang disediakan pada perpustakaan harus beragam, menarik, terbarukan serta disesuaikan dengan kebutuhan pengguna sehingga segala kebutuhan informasi pengguna dapat 
terpenuhi. Pengembangan perpustakaan kafe yang bertujuan untuk menarik minat baca sudah tentu harus menyediakan koleksi yang diminati oleh pengguna sehingga hal ini akan menarik minat pengunjung untuk membaca koleksi yang ada. Koleksi yang disediakan di perpustakaan kafe semestinya beragam, menarik, ringan namun tetap memperhatikan kualitas koleksi yang dipajang. Pada saat ini kebanyakan masyarakat lebih suka membaca buku yang bergaya bahasa ringan dan menekankan unsur rekreatif (Muetia, 2015). Dengan penyediaan koleksi yang demikian maka akan menarik minat pengunjung untuk membaca koleksi yang ada. Selain itu perpustakaan juga perlu menyediakan koleksi khusus yang berkualitas yang memuat ilmu dan informasi terkini yang penting untuk perkembangan ilmu pengetahuan sehingga informasi yang diperoleh dari membaca buku di perpustakaan kafe ini dapat menambah pengetahuan. Mengawali pengembangan perpustakaan kafe sebagai media peningkatan minat baca dapat dilakukan dengan menyediakan koleksi yang disukai tingkat remaja misalnya komik. Dengan pengubahan konsep perpustakaan yang dulunya kaku, sangat formal dan penuh aturan dimodifikasi menjadi ruangan yang nyaman dan santai, maka perpustakaan akan memiliki daya tarik pengguna untuk mengunjungi perpustakaan dan membaca koleksi yang ada sambil menikmati kenyamanan yang tersedia. Hal ini tentunya akan menjadi landasan dasar dalam upaya meningkatkan minat baca dikalangan kawula muda.

Perpustakaan perlu tetap memperhatikan konsep dasar hukum dari perpustakaan yang di cetuskan oleh Ranganathan (1931) diantaranya:

1. Books are for use (buku harus dimanfaatkan)

Setiap buku harsu digunakan atau dimanfaatkan. Pernyataan ini artinya bahwa setiap buku yang ada diperpustakaan harus digunakan atau dimanfaatkan oleh pengguna sehingga tidak ada buku yang tidak pernah tersentuh atau dibaca oleh pengguna.
2. Every reader his book (setiap pembaca tersedia bukunya)

Pernyataan ini menyatakan bahwa perpustakaan harus menyediakan koleksi yang dibutuhkan oleh pengguna sehingga pengguna mendapatkan jawaban atas informasi yang dibutuhkannya. Setiap perpustakaan harus mampu menyediakan koleksi dan informasi yang dibutuhkan oleh pengguna. Perpustakaan perlu mengetahui pengguna atau pengunjung perpustakaan sehingga perpustakaan mampu menyediakan koleksi yang dibutuhkan pembaca.

3. Every book its reader (setiap buku terdapat pembacanya)

Dalam pengadaan koleksi perpustakaan perlu melakukan analisis terhadap /survey mengenai buku yang dibutuhkan pengguna. Perpustakaan perlu melakukan mengetahui informasi atau buku yang dibutuhkan oleh pengguna. Selain itu juga disesuaikan dengan visi misi dan jenis perpustakaannya. Hal ini akan dapat digunakan sebagai acuaan pengembangan koleksi di perpsutakaan sehingga buku-buku yang ada di perpustakaan semuanya dapat dimanfaatkan atau dibaca oleh pengguna.

4. Save the time of the reader (menghemat waktu pembaca)

Di era serba cepat saat ini perpustakaan harus dapat memberikan layanan yang tepat dan cepat. Pengguna saat ini lebih mengutamakan sumber informasi yang mampu memberikan informasi secara tepat dan cepat sehingga perpustakaan harus mampu memberikan informasi yang dibutuhkan pengguna secara tepat dan cepat. Layanan penelusuran, layanan refrensi, penelusuran koleksi harus dapat dilakukan secara cepat. Begitu juga layanan lainnya seperti sirkulasi harus dapat dilakukan dengan cepat menghemat waktu pembaca

5. A library is a growing organism (perpustakaan bagaikan organisme yang selalu tumbuh)

Sebagai sumber informasi perpustakaan harus mampu melakukan perubahanperubahan dan terus dikembangkan 
sesuai dengan perkembangan teknologi informasi yang terjadi sehingga mampu bersaing dnegan sumber informasi lainnya.

d) Desain Teknis Ruangan

Pada perpustakaan kafe desain ruangan perpustakaan didesain semirip mungkin dengan kafe dengan meja dan kursi yang nyaman, ruangan bersih, penataan perabotan dan buku yang rapi sehingga mampu menciptakan suasana yang nyaman, santai bagi pengunjung serta tempat kerja yang efisien, nyaman, dan menyenangkan bagi staf perpustakaan (Siregar, 2008). Penataan ruangan dalam perpustakaan kafe perlu dipertimbangkan terutama kenyamanan pengguna serta media pendukung utama lainnya yang wajib disediakan dalam sebuah perpustakaan seperti meja baca, meja sirkulasi, penelusuran informasi, catalog koleksi dan lain sebagainya yang kesemuanya ditata ala kafe.

e) Kemitraan / Sponsorship

Sebagai lembaga non profit, dalam pengembangan perpustakaan kafe perlu melakukan kerjasama dengan pihak lain sebagai pihak yang bertanggungjawab dalam penyediaan makanan dan minuman atau sebagai penyandang dana dalam penyediaan makanan dan minuman di perpustakaan. Untuk mengoptimalkan pelayan di bidang informasi, perpustakaan perlu melakukan kerjasama baik dengan lembaga perpustakaan atau lembaga lain. Kerjasama dapat dilakukan dalam penyediaan sumber daya, data (resource sharing) dan kerjasama pertukaran koleksi dengan perpustakaan lain melalui silang layan. Melalui kerjasama ini maka memungkinkan informasi yang dibutuhkan pengguna akan terpenuhi.

Dengan pengembangan perpustakaan kafe ini diharapkan dapat menjadikan perpustakaan sebagai tempat untuk berkumpul, berinteraksi dan berdiskusi dengan nyaman seperti yang mereka peroleh dalam sebuah kafe serta dengan konsep kafe ini dapat merubah citra perpustakaan yang terlihat serius, tenang dan membosankan menjadi tempat yang menyenangkan.

Dalam pelayanan perpustakaan kafe perlu menetapkan beberapa aturan sehingga kegiatan perpustakaan dapat berjalan secara optimal diantaranya:

a. Layanan

Perpustakaan perlu menetapkan dan menjelaskan mengenai jenis layanan yang disediakan dalam perpustakaan kafe misalnya layanan sirkulasi (peminjaman buku) atau hanya layanan membaca di tempat. Begitu juga layanan pemesanan, pembayaran makanan dan minuman yang ada di perspustakaan kafe perlu ditetapkan dan disosialisasikan, sehingga mengoptimalkan layanan perpustakaan kafe.

b. Pengunjung dan Keanggotaan

Dalam perpustakaan kafe, keanggotaan dan pengujung yang boleh berkunjung ke perpustakaan dapat ditentukan berdasarkan jenis perpustakaannya.

c. Ketentuan mengenai larangan dan sanksi.

Perpustakaan kafe perlu secara tegas menetapkan peraturan-peraturan yang diberlakukan. Perpustakaan kafe harus secara jelas menetapkan mengenai yang diperbolehkan dan yang dilarang saat mengunjungi perpustakaan kafe. Salah satu contoh yang bisa ditetapkan adalah mengenai kesopanan berpakaian, sanksi apabila merusak buku dan lain-lain.

\section{KESIMPULAN}

Perpustakaan kafe merupakan model pengembangan perpustakaan unik yang saat ini memungkinkan untuk dikembangkan dalam upaya meningkatkan minat baca masyarakat Indonesia serta merupakan tempat yang dapat dikembangkan sebagai media interaksi sosial bagi masyarakat yang memiliki sedikit waktu untuk dapat berkumpul dengan para sahabat maupun keluarga. Adanya perpustakaan ini diharapkan masyarakat akan betah di perpustakaan sehingga dapat meningkatkan minat untuk membaca koleksi yang ada diperpustakaan yang kedepannya dapat meningkatkan kecerdasan, kualitas dan daya saing bangsa. 


\section{DAFTAR PUSTAKA}

--.-. 2012. Kamus Besar Bahasa Indonesia. Badan Pengembangan dan Pembinaan Bahasa. http://kbbi.web.id/kafe. Diakses tanggal 30 Mei 2016

2007. Undang-Undang No.43 tahun 2007 tentang Perpustakaan. Perpustakaan Nasional Republik Indonesia. 2008

Anonim. 2014. Hari Kunjung Perpustakaan dan Bulan Gemar Membaca. Kompasiana, 15 September 2014.

http://www.kompasiana.com/kemenkeulib/ hari-kunjung-perpustakaan-dan-bulangemar-membaca2014 54f5d4f7a333114a4f8b4647. Diakses tanggal 2 Februari 2016.

Anonim ${ }^{b}$. 2013. Perpustakaan. Media Keuangan Vol. VIII | No. 68 / April 2013 http://www.kemenkeu.go.id/sites/default/file s/media\%20keuangan/Media\%20Keuanga n\%20April\%202013/HTML/files/assets/basi c-html/page45.html

Abreu, C.R. 2015. The importance of reading. http://www.portoeditora.pt/conteudos/eman uais pe 2015 amostra/85309/9789720853 097-TE-

1/assets/resources/documents/sw9 reading .pptx . Diakses tanggal 14 maret 2015.

Acosmin. 2013. Why To Read: 10 Reasons Why Reading Books Will Save Your Life. http://whytoread.com/why-to-read-10reasons-why-reading-books-will-save-yourlifel. Diakses tanggal 4 Maret 2015.

Ansyori HR. 2013. Menumbuhkan Minat Baca Sebagai Upaya Meningkatkan Kualitas Sumber Daya Manusia. http://docplayer.info/345608Menumbuhkan-minat-baca-sebagai-upayameningkatkan-kualitas-sumber-dayamanusia-hanif-ridho-ansyori-pls-um.html. Diakses tanggal 21 Mei 2016
Basuki,S. 2003. Pengantar IImu Perpustakaan, Jakarta: Universitas Terbuka.

Benaw, I. 2012 Perpustakaan Kafe dan Warkop adalah Sebuah Perpustakaan Inovasi Masa Kini Jurnal Iqra' Volume 06 No.02 Okt, 2012. http://oaji.net/articles/2015/19371429787952.pdf. Diakses tanggal 25 Mei 2016

Chandra, RS. 2015. Perancangan Cafe-Library and Resto di Surabaya . Jurnal Intra Vol. 3, No. 2, (2015) 471-477. http://download.portalgaruda.org/article.php ?article $=336810 \& \mathrm{val}=6514 \&$ title $=$ Perancan gan\%20Cafe-

Library\%20and\%20Resto\%20di\%20Suraba ya . Diakses tanggal 22 Mei 2016

Erawan, LF. 2014. Peran pengelola dalam optimalisasi minat baca masyarakat di TBM Sukamulya Cerdas Kelurahan Sukamulya Kecamatan Cinambo Kota Bandung Universitas Pendidikan Indonesia.

http://repository.upi.edu/11333/4/T PLS 0 808369 Chapter1.pdf. Diakses tanggal 31 Mei 2016

Hardono, I. 2016. Bacalah, maka kamu pandai menulis. Kompas.com, 22 Februari 2016

http://edukasi.kompas.com/read/2016/02/22 117110071/Bacalah.Maka.Kamu.Pandai.Me nulis. Diakses tanggal 15 Maret 2016.

Haryanti, T. 2010. Inovasi Pengembangan Dan Pemberdayaan Perpustakaan Masyarakat. http://www.triniharyanti.id/2010/04/inovasipengembangan-dan-pemberdayaan.html, diakses tanggal 23 Mei 2016

International of Library Associationsand Institutions (IFLA) .2015. IFLA Statement on Libraries and Development. http://www.ifla.org/publications/iflastatement-on-libraries-and-development. Diakses tanggal 24 Mei 2016

Kamsul K, -. Strategi Pengembangan Minat Dan Gemar Membaca 
http://e-

dokumen.kemenag.go.id/files/G4pKDLun13 38123296.pdf, diakses tanggal 23 Mei 2016

Kartika,I. 2012. Nongkrong" di cafe jadi gaya hidup.

http://www.antaranews.com/berita/300726/ nongkrong-di-cafe-jadi-gaya-hidup diakses tanggal 1 Agustus 2016

Khoiri I. 2015. Membaca sebagai jendela untuk melihat dunia. Kompas, 19 Mei 2015. http://print.kompas.com/baca/2015/05/19/M embaca-sebagai-Jendela-untuk-MelihatDunia?utm source=RD\&utm medium=inart \&utm campaign $=k$ hiprd .Diakses tanggal 14 Maret 2016.

Kompas.2016. Minat Baca Rendah, Mayoritas Warga Indonesia Hobi Nonton Televisi. Kompas, Kamis, 28 April 2016. http://regional.kompas.com/read/2016/04/2 8/21020061/Minat.Baca.Rendah.Mayoritas. Warga.Indonesia.Hobi.Nonton.Televisi

Lasa. 2007. Manajemen Perpustakaan Sekolah. Yogyakarta: Pinus.

Manis, H. 2010. Learning is Easy: Tip dan Panduan praktis agar belajar jadi Asyik, Efektif, dan Menyenangkan. Jakarta.PT Elex Media Komputindo.

Muetia.M.S. 2015. Novel sastra populer untuk tumbuhkan minat baca. Kompas, 21 September 2015 .http://print.kompas.com/baca/2015/09/21/ Novel-Sastra-Populer-untuk-TumbuhkanMinat-Baca?utm source=bacajuga. Diakses tanggal 23 Maret 2016.

Musa, N. 2012. Layanan Referensi Multi Akses Berbasis Website Melalui "Bookmarking". http://www.academia.edu/3236731/Layanan Referensi Multi Akses Berbasis Website Melalui Bookmarking .Diakses tanggal 30 Mei 2016.

Ngasuko.T.A.2015. Daya Saing Sumber Daya Manusia Indonesia Menghadapi Masyarakat Ekonomi ASEAN . http://www.kemenkeu.go.id/en/node/48120 diakses tanggal 1 April 2016.

Radesi, D. 2013. Pengaruh Penerapan Model Concentrated Language Encounter (CLE) terhadap Kemampuan Membaca Pemahaman Bahasa Inggris Ditinjau dari Motivasi Berprestasi Siswa Kelas XI di SMA Negeri 2 Amlapura.

http://download.portalgaruda.org/article.ph p?article $=258815 \& \mathrm{val}=7029 \&$ title $=$ PENGA RUH\%20PENERAPAN\%20MODEL\%20C ONCENTRATED\%20LANGUAGE\%20EN COUNTER\%20\%28CLE\%29\%20TERHAD AP\%20KEMAMPUAN\%20MEMBACA\%20 PEMAHAMAN\%20BAHASA\%20INGGRIS \%20DITINJAU\%20DARI\%20MOTIVASI\%2 OBERPRESTASI\%20SISWA\%20KELAS\% 20XI\%20DI\%20SMA\%20NEGERI\%202\%2 OAMLAPURA. Diakses tanggal 30 Mei 2016.

Ranganathan, S. R. 1931. The Five Laws of Library Science. London: Edward Goldston.

Rochadita, B. 2010. Pengaruh Lokasi Perpustakaan Umum Kabupaten Sukoharjo Terhadap Minat Berkunjung Pelajar SMP. Skripsi. Universitas Diponegoro. Semarang.

http://eprints.undip.ac.id/21876/1/halaman judul skripsi2.pdf. Diakses tanggal $31 \mathrm{Mei}$ 2016

Sainttyauw, AACZJ. 2013. Pengaruh Desain Interior Perpustakaan Terhadap Kenyamanan Pengguna Di Perpustakaan Universitas 17 Agustus 1945 Surabaya. http://journal.unair.ac.id/downloadfullpapers-Jurnal\%20Adrina.pdf

Setiati, G. 2015. Gender dan place attachmentpada coffee shop di Bandung http://journals.itb.ac.id/index.php/sostek/arti cle/download/1372/1067. diakses tanggal 15 Maret 2016.

Siregar, Belling. 2008. Gedung dan Perlengkapan Perpustakaan. Medan : Program Studi Ilmu Perpustakaan Universitas Sumatera Utara. 
Sularsih,S. 2015. Ini Penyebab Rendahnya Minat Baca. Okezone, 17 November 2015 http://news.okezone.com/read/2015/11/17/6 5/1250673/ini-penyebab-rendahnya-minatbaca diakses tanggal 25 Maret 2016.

Supriadi, A. 2015. WEF: Daya Saing Indonesia Turun ke Peringkat 37 Dunia, CNN Indonesia.

http://www.cnnindonesia.com/ekonomi/201 51002162426-92-82410/wef-daya-saingindonesia-turun-ke-peringkat-37-dunia diakses tanggal 2 Februari 2016.

Sutarno, N.S. 2003. Perpustakaan dan Masyarakat, Jakarta: Yayasan Obor Indonesia.

Sutarno, N.S. 2006. Perpustakaan dan Masyarakat Eds. Rev. Jakarta: Sagung Seto.

Suwanto SA.2013. Layanan perpustakaan elektronik dengan konsep Library 2.0. http://eprints.undip.ac.id/35023/2/Layanan perpustakaan dengan konsep Library 2 0 \%2B abstrk.pdf diakses tanggal 25 Mei 2016.

Taylor G. S, 2015. Minat Baca Masyarakat Indonesia Masih Rendah, Benarkah?Majalah Kartini, http://majalahkartini.co.id/berita/minat-bacamasyarakat-indonesia-masih-rendahbenarkah dikases 5 Februari 2016

Tjiptono, F. 2004. Manajemen Jasa. Yogyakarta: Andi Ofset. 